Journal of Agricultural Sciences
(Tarim Bilimleri Dergisi)

\title{
The Effect of Maize (Zea mays L.) / Soybean (Glycine max (L.) Merr.) Intercropping and Biofertilizer (Azotobacter) on Yield, Leaf Area Index and Land Equivalent Ratio
}

\author{
Aydin UNAY ${ }^{a *}\left(\mathbb{D}\right.$, Ibrahim SABANCI ${ }^{b}(\mathbb{D})$, Volkan Mehmet CINAR ${ }^{c}$ (iD \\ ${ }^{a}$ Aydin Adnan Menderes University, Agricultural Faculty, Department of Field Crops, Aydin, TURKEY

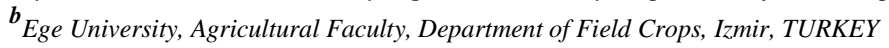

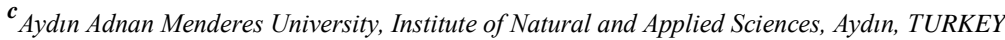

ARTICLE INFO

Research Article

Corresponding Author: Aydın UNAY, E-mail: aunay@ adu.edu.tr

Received: 31 May 2019 / Revised: 01 August 2019 / Accepted: 15 December 2019 / Online: 18 January 2021

\section{ABSTRACT}

This study was conducted to determine the effects of the different intercropping design of maize/soybean compared with sole cropping, in combination with Vitormone (biofertilizer; Azotobacter) during 2012 and 2013. There were four different intercropping designs were used in the experiment: $i$ ) sole maize and soybean, ii) 1 maize +1 soybean in alternate rows, iii) 1 maize +2 soybeans in alternate rows and $i v) 1$ maize +2 soybeans in intra rows under control with the Vitormone application. The experiment was laid out in a randomized complete block design with two factors and three replications. The results showed that the seed/grain yields and the Leaf area index of sole soybean and sole maize outperformed the intercropping. The highest yields for both maize $(8.0 \mathrm{t}$ $\mathrm{ha}^{-1}$ ) and soybean (3.26 t ha-1) and land equivalent ratio (1.26) were recorded at 1 maize +2 soybeans in alternate rows among the intercropping. The effect of Vitormone was significantly positive for all cropping system except 1 maize +1 soybean in alternate rows. This suggests that 1 maize +2 soybeans in alternate rows can intercrop and combine with the Vitormone. The intercropping of cereal/legume has the potential to improve the utilization of resources in monocropped lands.

Keywords: Alternate row and intra row, Intercropping, LAI (leaf area index), LER (land equivalent ratio), the Vitormone

(C) Ankara University, Faculty of Agriculture

\section{Introduction}

Intercropping can be defined as a multiple cropping system that two or more crops planted in a field during a growing season (Yong et al. 2015). Intercropping is a way to increase diversity in an agricultural ecosystem. The most benefit of intercropping is optimum utilization of plant resources such as nitrogen in Gramineae (or Poaceae)/Legumes (or Fabaceae) intercropping (Nasri et al. 2014). As known, Legume crop is used as soil $\mathrm{N}$ supply. When the crop with large canopy intercropped with the small crops, such as maize and soybean intercropping, soybean yield could decrease due to interspecific light competition (Liu et al. 2017). Thus, different intercropping designs such as alternate rows and intra rows were studied in many types of research (Ijoyah \& Fanen 2012; Mandal et al. 2014). The optimum inter-row and intra-row distances are the most important to produce a high yield in maize/soybean intercropping (Kim et al. 2018). The LER has been recommended to evaluate the yield advantage of intercropping compared to monocropping (Mahallati et al. 2014). It was reported that the LER values above 1 determined in maize/soybean intercropping (Dolijanvic et al. 2009; Tsujimoto et al. 2015; Kamara et al. 2017).

The Büyük Menderes Basin has a typical Mediterranean climatic characteristic. Although monocropped cotton grown in many areas with saline and alkali soils, agricultural production is intensive, with winter wheat or forage crops-summer cotton or maize rotation. Yavas \& Unay $(2016 \mathrm{a}, \mathrm{b})$ stated that poor nodulation of soybean and cowpea with maize intercropping occurred in the west of Büyük Menderes Basin. Nodulation failure is caused by soil compaction, flooding, and high pH levels. Vitormone is one of the foliar liquid bio-fertilizers containing Azotobacter chroococcum which species responsible for atmospheric nitrogen fixation (Mohiuddin et al. 2000; Ramteke et al. 2016). In many studies, it concluded that the Vitormone promoted the plant growth (Ghosh \& Dayal 1998; Gaikwad et al. 2008).

There are few published reports on the poor nodulating of legume in grain/legume intercropping and interaction of biofertilizer (the Vitormone) and different intercropping design. Therefore, we conducted the present study to (a) determine the yield performance in maize and soybean intercropping under the Vitormone application; (b) explore the optimum intercropping design. 


\section{Material and Methods}

\subsection{Field layout and plant materials}

This study was carried out at the field of research and application ( $37^{\circ} 45^{\prime}$ North, $27^{\circ} 45^{\prime}$ East) of the Field Crops Department of the Agricultural Faculty of Aydin Adnan Menderes University during the summer of the 2012 and 2013. The area is affected by a Mediterranean type of climate with hot and dry summer (Sensoy et al. 2007). The mean temperatures from April to September show that July and August exceed the long term mean temperatures (Figure 1) (provided by the Turkish State Meteorological Service).

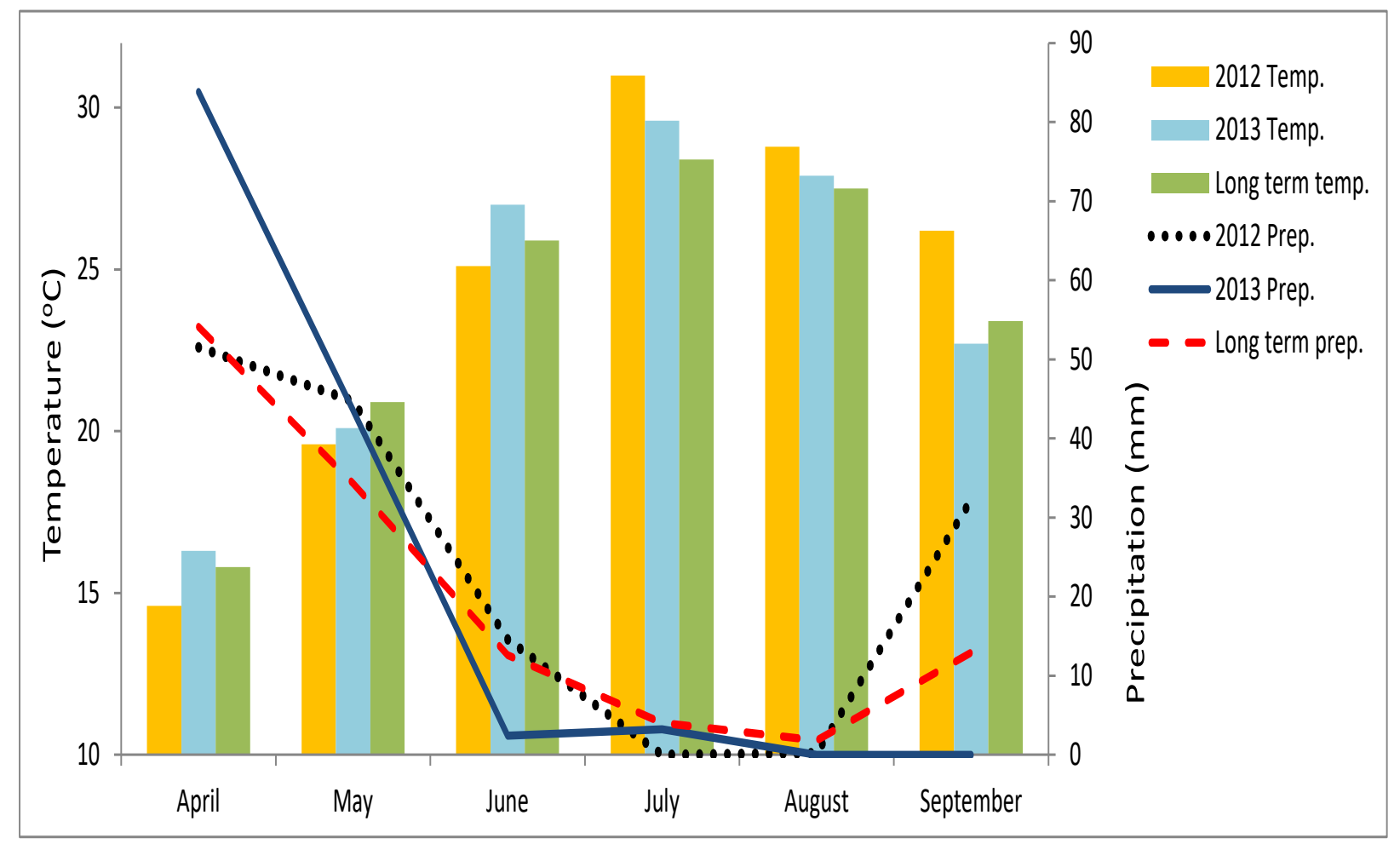

Figure 1- Precipitation and temperature during the cropping season in 2012 and 2013 with a long period

The experiment was sown on loamy sand soil having pH 7.60 (slight alkali), organic matter level is $1.20 \%$ (insufficient), total nitrogen $0.095 \%$ (medium), available $\mathrm{P}_{2} \mathrm{O}_{5}$ level is $2.08 \mathrm{mg} \mathrm{kg}^{-1}$ (insufficient) and available $\mathrm{K}_{2} \mathrm{O}$ level is $1528 \mathrm{mg} \mathrm{kg}{ }^{-1}$ (medium) (provided by Aegean University soil analysis laboratory).

P31G98 hybrid maize (Zea mays L.) and Umut soybean cultivar (Glycine max (L.) Merr.) were used as plant material. The soil characteristics where the experiment is carried out are alkali and poor in organic matter due to monoculture cotton growing. For this reason, it was difficult the nodulation of soybean. Therefore, Vitormone has been used as a factor in the application of biological fertilizer. The Vitormone provides the optimal environment for activating leaf surfaces by organisms and promotes a rich flora formation on the leaf surface (Golenberg \& West 2013; Uddin et al. 2014).

In the study, "Randomized Complete Blocks Design with Two Factors" was used to simultaneously investigate the effects of intercropping and biofertilizer (the Vitormone) application (Cochran \& Cox 1950). Sowings were carried out in 3 replications on May 1, 2012, and May 7, 2013. As a second factor, maize and soybean sowings were arranged as alternate rows, intra row and sole. The list of crops design in intercropping is given in Table 1 and schematized in Figure 2.

Sole maize $\left(\mathrm{M}_{\mathrm{B}}\right)$ was planted at $0.70 \times 0.15 \mathrm{~m}$ and soybean $\left(\mathrm{S}_{\mathrm{B}}\right)$ planted at $0.70 \times 0.05 \mathrm{~m}$ sowing standards. Each parcel consists of 12 rows $\left(42 \mathrm{~m}^{2}\right)$ with a length of $5 \mathrm{~m}$. The alternate rows were planted with 1 row of maize and 1 row of soybean and $35 \mathrm{~cm}$ rows and $15 \mathrm{~cm}$ and $5 \mathrm{~cm}$ rows respectively in the sowing areas $\left(\mathrm{MS}_{\mathrm{A}}\right)$. There are approximately $90,000 \mathrm{plants}^{-1} \mathrm{maize}^{-}$ and 285,500 plants $\mathrm{ha}^{-1}$ soybean in the areas of plain seed and alternate seeding with soybean cultivation. These parcels consist of 24 rows with a length of $5 \mathrm{~m}\left(42 \mathrm{~m}^{2}\right)$. Another alternate sequence was 1 maize +2 soybean cultivars $\left(\mathrm{MS}_{\mathrm{D}}\right)$, and $1.05 \mathrm{~m} \mathrm{x}$ $0.15 \mathrm{~m}$ sowing norm for maize and $0.35 \mathrm{~m}$ x $0.05 \mathrm{~m}$ sowing norm for soybeans were applied. In this regard, the plant densities

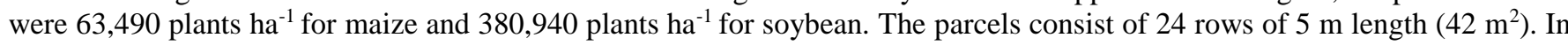
the sowing on the same row $\left(\mathrm{MS}_{\mathrm{C}}\right)$ parcels, two soybeans with $0.05 \mathrm{~m}$ space were $0.25 \mathrm{~m}$ between two maize. The plant densities were 57,140 plants $\mathrm{ha}^{-1}$ for maize and 114,280 plants $^{-1} \mathrm{a}^{-1}$ for soybean. 


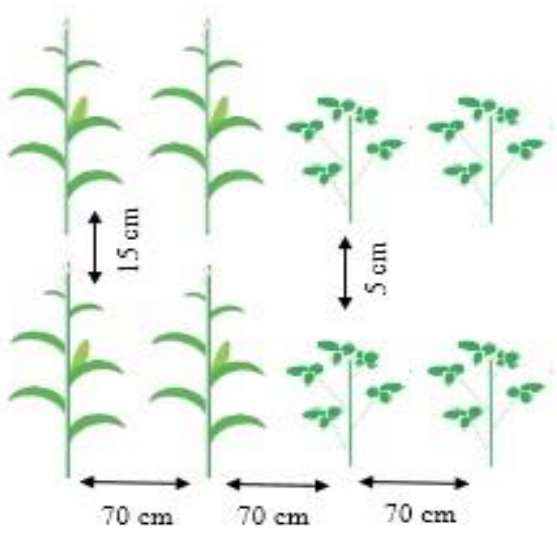

MB Sole maize SB Sole soybean

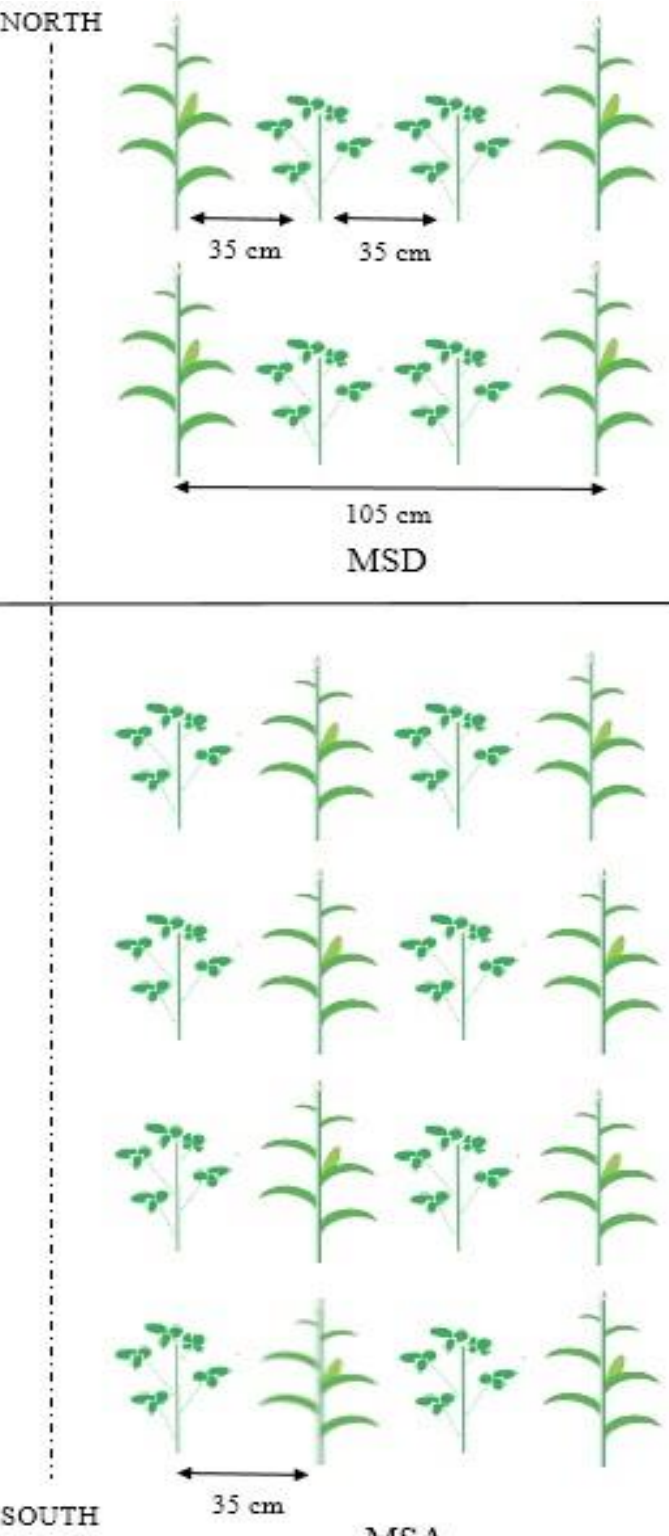

MSC
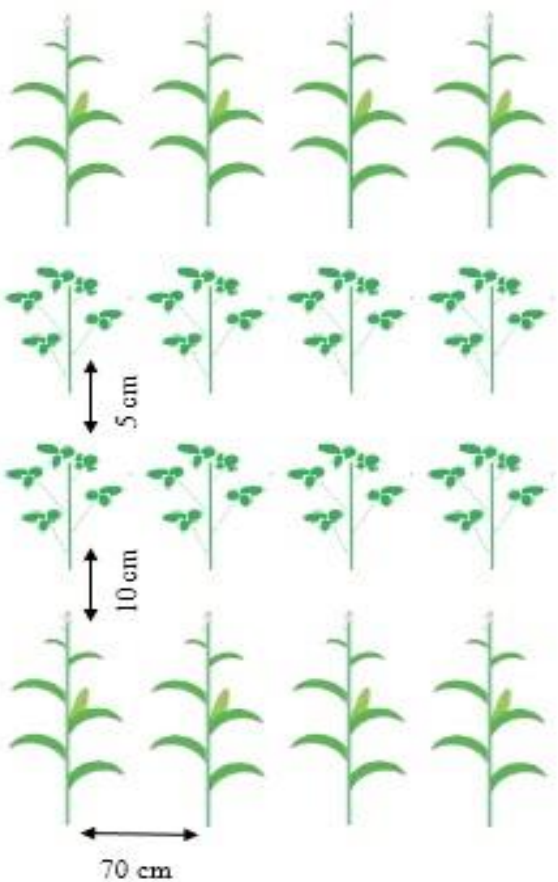

SOUTH

MSA

Figure 2- Diagrammatic sketch of different maize-soybean intercropping system

Table 1- The list of crops design in the cropping system

\begin{tabular}{|c|c|c|}
\hline Crop & Crop Design in intercropping & Symbol \\
\hline Maize & Sole & $\mathrm{M}_{\mathrm{B}} \mathrm{V}^{-}$ \\
\hline Soybean & Sole & $\mathrm{S}_{\mathrm{B}} \mathrm{V}^{-}$ \\
\hline Maize & Sole + Vitormone & $\mathrm{MBV}^{+}$ \\
\hline Soybean & Sole + Vitormone & $\mathrm{S}_{\mathrm{B}} \mathrm{V}^{+}$ \\
\hline 1 Maize + 1 Soybean & Alternate Rows & $\mathrm{MS}_{\mathrm{A}} \mathrm{V}^{-}$ \\
\hline 1 Maize + 1 Soybean & Alternate Rows + Vitormone & $\mathrm{MS}_{\mathrm{A}} \mathrm{V}^{+}$ \\
\hline 1 Maize +2 Soybean & Alternate Rows & $\mathrm{MS}_{\mathrm{D}} \mathrm{V}^{-}$ \\
\hline 1 Maize +2 Soybean & Alternate Rows + Vitormone & $\mathrm{MS}_{\mathrm{D}} \mathrm{V}^{+}$ \\
\hline 1 Maize +2 Soybean & Intra row & $\mathrm{MS}_{\mathrm{C}} \mathrm{V}^{-}$ \\
\hline 1 Maize +2 Soybean & Intra row + Vitormone & $\mathrm{MSCV}^{+}$ \\
\hline
\end{tabular}

For all parcels, the recommended fertilizer rate of 180:80:80 of NPK was applied using a compound fertilizer (NPK 15:15:15) to supply $80 \mathrm{~kg}$ each of NPK ha-1 before sowing as basal application. Urea (46\% N) to supply the remaining dose $\left(100 \mathrm{~kg} \mathrm{ha}^{-1}\right)$ of nitrogen was applied before first irrigation for all parcels except sole soybean. Three hoeings were applied for weeding. The Vitormone (Biological fertilizer) application, which is a factor in our study, prepared the Vitormone application (1 mL Vitormone +1 -L water which is the recommended the dose of Vitormone solution). It was applied twice with the mechanical back-sprayer at the flowering stage and 1 week after flowering in soybean. 


\subsection{Yield}

For the yield of maize and soybean; 20 tagged plants were randomly selected from two rows of each plot leaving the outside rows as borders, and all obtained data were corrected to $14 \%$ grain moisture for both crops (Nyoki \& Ndakidemi 2018).

\subsection{Leaf area index (LAI)}

For the LAI, data were collected from twenty plants at two the middle rows of each parcel at the stage of silking/tasseling for maize and peak flowering for soybean (Liu et al. 2017). The samples were separated into leaves. Leaf width and length measured in all leaves maize and multiplied to a coefficient factor of 0.75. Single leaf area for soybean was measured using an LI-3100 (LI-COR, Lincoln, NE) leaf area meter device. The LAI $\left(\mathrm{m}^{2} \mathrm{~m}^{-2}\right)$ was determined by taking into account the number of plants in the unit area.

\subsection{Land equivalent ratio (LER)}

The LER is widely used to evaluate the land productivity of intercropping and was calculated according to the following formula (Ofori \& Stern 1987);

$\mathrm{LER}=[$ Intercropping maize yield /Sole maize yield $]+[$ Intercropping soybean yield /Sole soybean yield $]$

LER > 1 was evaluated as an effective intercropping system in terms of land utilization.

\subsection{Statistical analysis}

The data of yield and LAI were statistically analyzed using TARIST statistical Package Program (Acikgoz et al. 1994). The differences between the means were compared by the least significant difference (LSD) at the 5\% level.

\section{Results and Discussion}

The results from the present study indicated that interactive effects of intercropping design and Vitormone application for maize yield were significant in the 2012 and 2013 cropping seasons. The high maize yields recorded in sole maize with the Vitormone (16.2 and 15.3 $\mathrm{t} \mathrm{ha}^{-1}$ ) and the non-Vitormone plots (14.9 and 14.3 $\mathrm{t} \mathrm{ha}^{-1}$ ) compared to intercropping plots (Table 2). In both years, $\mathrm{MS}_{\mathrm{D}} \mathrm{V}^{+}\left(8.0 \mathrm{t} \mathrm{ha}^{-1}\right)$ and $\mathrm{MS}_{\mathrm{C}} \mathrm{V}^{+}\left(7.0\right.$ and $\left.7.6 \mathrm{t} \mathrm{ha}^{-1}\right)$ parcels produced the yields of the second group. In the parcels $\left(\mathrm{MS}_{\mathrm{A}}\right)$ which alternate rows were planted with 1 row of maize and 1 row of soybean, maize yields of the non-Vitormone applications were higher than that of the Vitormone applications in both years.

Table 2- The results of variance analysis for the yield

\begin{tabular}{lcccccc}
\hline Source of variation & $d f$ & \multicolumn{3}{c}{ Yield } \\
\hline & & \multicolumn{2}{c}{ Maize } & & \multicolumn{2}{c}{ Soybean } \\
\cline { 3 - 6 } & & 2012 & 2013 & & 2012 & 2013 \\
\cline { 3 - 6 } Block & 2 & 14091.56 & 3826.54 & & 66.14 & 332.65 \\
Vitormone (A) & 1 & 321.20 & $2795.04^{*}$ & & $15595.80^{* *}$ & $14113.50^{* *}$ \\
Crop Design (B) & 3 & $1041140.43^{* *}$ & $849598.15^{* *}$ & & $164448.33^{* *}$ & $133185.98^{* *}$ \\
Ax B & 3 & $80637.43^{* *}$ & $11888.26^{* *}$ & & $3885.59^{* *}$ & 682.18 \\
Error & 14 & 4540.51 & 515.83 & & 126.93 & 620.48 \\
\hline
\end{tabular}

*,**; significant at $5 \%$ and $1 \%$ probability level, respectively

The interaction of intercropping design and the Vitormone application was significant for soybean yield in 2012 whereas the differences of intercropping designs and the Vitormone applications were found significant in 2013. The yields of sole soybean parcels were higher than intercropping parcels in the Vitormone $\left(4.8 \mathrm{t} \mathrm{ha}^{-1}\right)$ and the non-Vitormone $\left(3.7 \mathrm{t} \mathrm{ha}^{-1}\right) \mathrm{parcels}(\mathrm{Table} 3)$. These values followed by $\mathrm{MS}_{\mathrm{D}} \mathrm{V}^{+}\left(3.4 \mathrm{tha}^{-1}\right)$ and $\mathrm{MS}_{\mathrm{D}} \mathrm{V}^{-}\left(2.8 \mathrm{tha}^{-1}\right)$. The yields of $\mathrm{MS}_{\mathrm{C}}$ and $\mathrm{MS}_{\mathrm{A}}$ extensively decreased compared to sole cropping and $\mathrm{MS}_{\mathrm{D}}$. In 2013, sole soybean had the highest yield (4.3 tha-1) and was followed by $\mathrm{MS}_{\mathrm{D}}\left(3.2 \mathrm{t}\right.$ ha $\left.{ }^{-1}\right) . \mathrm{Also}_{\mathrm{s}}$, the yield of soybean in the Vitormone application recorded higher yield of $2.8 \mathrm{t} \mathrm{ha}^{-1}$ compared to the non-Vitormone $\left(2.3 \mathrm{t}\right.$ ha $\left.{ }^{-1}\right)$. Several studies (Ijoyah \& Fanen 2012; Khan et al. 2012; Undie et al. 2012; Verdelli et al. 2012; Hirpa 2013; Ijoyah et al. 2013; Osang et al. 2014) suggested that the maize and soybean yield of intercropping over sole cropping decreased due to interspecific competition. In intercropping systems, yield advantage for maize and soybean could be found, which does not support findings of Li et al. (2001), Ngwira et al. (2012). Also, it was documented that the Vitormone application resulted with higher yield in 
the soybean (Tahir et al. 2009; Subowo et al. 2010; Koushal \& Singh 2011; Ngalamu et al. 2013; Salih et al. 2014), faba bean (Vicia faba L.) (Osman et al. 2010), chickpea (Cicer arietinum L.) (Uddin et al. 2014). The additional Vitormone application could be enhanced the yields of maize and soybean in especially poor nodulating conditions.

Table 3- Mean yield of the intercropping system and Vitormone application in 2012 and 2013

\begin{tabular}{|c|c|c|c|c|c|c|c|}
\hline & & & $\left.a^{-1}\right)$ & & & ybean & \\
\hline & & & & & & & 2013 \\
\hline & $V^{+}$ & $V^{-}$ & $V^{+}$ & $V^{-}$ & $V^{+}$ & $V^{-}$ & \\
\hline $\mathrm{A}$ & $6.2 \mathrm{e}$ & $9.6 \mathrm{c}$ & $6.2 \mathrm{f}$ & $7.3 \mathrm{e}$ & $0.8 \mathrm{e}$ & $0.9 \mathrm{e}$ & $1.3 \mathrm{c}$ \\
\hline B & $16.2 \mathrm{a}$ & $14.9 \mathrm{~b}$ & $15.3 \mathrm{a}$ & $14.3 \mathrm{~b}$ & $4.8 \mathrm{a}$ & $3.7 \mathrm{~b}$ & $4.3 \mathrm{a}$ \\
\hline $\mathrm{C}$ & $7.0 \mathrm{de}$ & $6.4 \mathrm{e}$ & $7.6 \mathrm{~d}$ & $7.2 \mathrm{e}$ & $1.3 \mathrm{~d}$ & $0.9 \mathrm{e}$ & $1.2 \mathrm{c}$ \\
\hline $\mathrm{D}$ & $8.0 \mathrm{~d}$ & $6.4 \mathrm{e}$ & $8.0 \mathrm{c}$ & $7.5 \mathrm{de}$ & $3.4 \mathrm{~b}$ & $2.8 \mathrm{c}$ & $3.2 \mathrm{~b}$ \\
\hline $\operatorname{LSD}_{(0.05)}$ & & & & & & & 0.30 \\
\hline $\mathrm{V}^{+}$ & & & & & & & $2.8 \mathrm{a}$ \\
\hline $\mathrm{V}^{-}$ & & & & & & & $2.3 \mathrm{~b}$ \\
\hline $\operatorname{LSD}_{(0.05)}$ & & & & & & & 0.2 \\
\hline
\end{tabular}

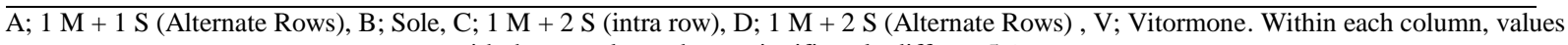
with the same letter do not significantly differ at $5 \%$

The LAI is a positive indicator to improve the yield and to minimize the evaporation (Kubota et al. 2015). Also, it is probably the most important factor in the competition for light and critical to maintaining high yield in intercropping (Kamara et al. 2017). The effects of interaction between the intercropping system and Vitormone application on the LAI were found to be significant for the maize in the 2012 and 2013; for the soybean in 2013 (Table 4). The differences in the intercropping system and the Vitormone application for the soybean in 2012 were significant. The LAI values of sole maize with Vitormone $\left(6.00 \mathrm{~m}^{2} \mathrm{~m}^{-2}\right)$ or without the Vitormone $\left(5.90 \mathrm{~m}^{2} \mathrm{~m}^{-2}\right)$ were significantly higher than intercropping parcels in 2012 (Table 5). MS $\mathrm{A}_{\mathrm{A}}$ plots significantly exhibited the highest LAI values $\left(4.41 \mathrm{~m}^{2} \mathrm{~m}^{-2}\right.$ and $\left.4.72 \mathrm{~m}^{2} \mathrm{~m}^{-2}\right)$ compared to other intercropping parcels, $\mathrm{MS}_{\mathrm{D}}$ and $\mathrm{MS}_{\mathrm{C}}$, respectively. The LAI values of 2013 growing season were similar to 2012 values for maize. In terms of the soybean's LAI, the sole soybean (7.28) had a significantly higher LAI value than that of intercropping systems followed by MS $\mathrm{D}_{\mathrm{D}}(6.40)$ in 2012. Similar ranging among the LAI values of intercropping systems in both $\mathrm{V}^{+}$and $\mathrm{V}^{-}$parcels were recorded for soybean. However, it should be noted that the sum of maize and soybean LAI in intercropping was always superior to sole maize and soybean (Walker \& Ogindo 2003; Kubota et al. 2015).

The LER provides an accurate evaluation of the competition in the intercropping system. Also, the LER of more than 1.0 reveals the yield advantage of intercropping. The LERs of different intercropping systems varied from $0.55\left(\mathrm{MS}_{\mathrm{A}} \mathrm{V}^{+}\right)$to 1.32 $\left(\mathrm{MS}_{\mathrm{D}} \mathrm{V}^{+}\right)$. In contrast to many published literature, there was no strong the LER above 1.50 in maize/soybean intercropping (Rahman et al. 2017; Chen et al. 2018). The yield capacities of mentioned studies were 5.63-8.53 $\mathrm{t} \mathrm{ha}^{-1}$ for the maize and 1.59$2.22 \mathrm{t} \mathrm{ha}^{-1}$ for soybean (Chen et al. 2018), 4.9-10.8 $\mathrm{t} \mathrm{ha}^{-1}$ for the maize and 0.11-1.85 $\mathrm{t} \mathrm{ha}^{-1}$ for soybean (Rahman et al. 2017), whereas yield values were 6.2-16.2 $\mathrm{t} \mathrm{ha}^{-1}$ for the maize and 0.8-4.8 $\mathrm{t} \mathrm{ha}^{-1}$ for the soybean in our study. It can be concluded that yield capacity should be considered when evaluating the LER, especially in the fertile areas. The $\mathrm{MS}_{\mathrm{D}}, 1 \mathrm{Maize}+2 \mathrm{Soybean}$ in alternate rows, produced greater than other intercropping systems (Table 6). The all LER values of Vitormone application parcels except MSA were found to be higher than the non-Vitormone application. In previous studies, it was documented that the highest LER value (1.26) was found in 1 maize + 2 soybeans in alternate rows (Addo-Quaye et al. 2011; Ijoyah \& Fanen 2012; Mandal et al. 2014). Especially, the yield losses of $\mathrm{MS}_{\mathrm{A}}$ and $\mathrm{MS}_{\mathrm{C}}$ resulted from the continuous shading of the maize, and soybean yield decreased (Lv et al. 2014; Liu et al. 2017).

Table 4- The results of variance analysis for the LAI

\begin{tabular}{lcrrrr}
\hline \multirow{2}{*}{ Source of variation } & $d f$ & \multicolumn{2}{c}{ Maize } & \multicolumn{2}{c}{ Soybean } \\
& & 2012 & 2013 & 2012 & 2013 \\
\hline Block & 2 & 0.01 & 0.00 & 0.02 & 0.00 \\
Vitormone (A) & 1 & 0.01 & 0.00 & $0.11^{*}$ & $0.11^{* *}$ \\
Crop Design (B) & 3 & $8.15^{* *}$ & $8.61^{* *}$ & $14.39^{* *}$ & $14.82^{* *}$ \\
A x B & 3 & $0.05^{* *}$ & $0.02^{* *}$ & 0.04 & $0.02^{* *}$ \\
Error & 14 & 0.00 & 0.00 & 0.01 & 0.00 \\
\hline
\end{tabular}

$*$,**; significant at $5 \%$ and $1 \%$ probability level, respectively. LAI; leaf area index 
Table 5- Mean LAI of the intercropping system and Vitormone application in 2012 and 2013

\begin{tabular}{|c|c|c|c|c|c|c|c|}
\hline & \multicolumn{4}{|c|}{ Maize $\left(m^{2} m^{-2}\right)$} & \multicolumn{3}{|c|}{ Soybean $\left(m^{2} m^{-2}\right)$} \\
\hline & \multicolumn{2}{|c|}{2012} & \multicolumn{2}{|c|}{2013} & \multirow[t]{2}{*}{2012} & \multicolumn{2}{|c|}{2013} \\
\hline & $V^{+}$ & $V^{-}$ & $V^{+}$ & $V^{-}$ & & $V^{+}$ & $V^{-}$ \\
\hline A & $4.41 \mathrm{c}$ & $4.72 \mathrm{~b}$ & $4.38 \mathrm{c}$ & $4.51 \mathrm{~b}$ & $4.72 \mathrm{c}$ & $4.81 \mathrm{e}$ & $4.78 \mathrm{e}$ \\
\hline $\mathrm{B}$ & $6.00 \mathrm{a}$ & $5.90 \mathrm{a}$ & $5.94 \mathrm{a}$ & $5.90 \mathrm{a}$ & $7.28 \mathrm{a}$ & $7.33 \mathrm{a}$ & $7.27 \mathrm{~b}$ \\
\hline $\mathrm{C}$ & $3.24 \mathrm{e}$ & $3.19 \mathrm{e}$ & $3.41 \mathrm{~d}$ & $3.28 \mathrm{e}$ & $3.84 \mathrm{~d}$ & $3.96 \mathrm{f}$ & $3.73 \mathrm{~g}$ \\
\hline $\mathrm{D}$ & $3.93 \mathrm{e}$ & $3.90 \mathrm{~d}$ & $3.47 \mathrm{~d}$ & $3.40 \mathrm{~d}$ & $6.40 \mathrm{~b}$ & $6.60 \mathrm{c}$ & $6.38 \mathrm{~d}$ \\
\hline $\operatorname{LSD}_{(0.05)}$ & \multicolumn{2}{|c|}{0.105} & \multicolumn{2}{|c|}{0.071} & 0.139 & \multicolumn{2}{|c|}{0.046} \\
\hline $\mathrm{V}+$ & & & & & $5.62 \mathrm{a}$ & & \\
\hline V- & & & & & $5.48 \mathrm{~b}$ & & \\
\hline $\operatorname{LSD}_{(0.05)}$ & & & & & 0.098 & & \\
\hline
\end{tabular}

A; $1 \mathrm{M}+1 \mathrm{~S}$ (Alternate Rows), B; Sole, C; $1 \mathrm{M}+2 \mathrm{~S}$ (intra row), D; $1 \mathrm{M}+2 \mathrm{~S}$ (Alternate Rows), V; Vitormone. Within each column, values with the same letter do not significantly differ at $5 \%$.

Table 6- The LER values for intercropping system and Vitormone application

\begin{tabular}{cccc}
\hline & & LER & \\
\hline Intercropping System & 2012 & 2013 & Mean \\
$\mathrm{MS}_{\mathrm{A}} \mathrm{V}^{-}$ & 0.88 & 0.76 & 0.82 \\
$\mathrm{MS}_{\mathrm{A}} \mathrm{V}^{+}$ & 0.55 & 0.70 & 0.63 \\
$\mathrm{MS}_{\mathrm{C}} \mathrm{V}^{-}$ & 0.67 & 0.72 & 0.69 \\
$\mathrm{MS}_{\mathrm{C}} \mathrm{V}^{+}$ & 0.70 & 0.85 & 0.78 \\
$\mathrm{MS}_{\mathrm{D}} \mathrm{V}^{-}$ & 1.19 & 1.21 & 1.20 \\
$\mathrm{MS}_{\mathrm{D}} \mathrm{V}^{+}$ & 1.20 & 1.32 & 1.26 \\
\hline
\end{tabular}

LER; Land equivalence ratio

\section{Conclusions}

The interaction of the intercropping design and the Vitormone were significant for yield and the LAI in both years. The Sole maize and the sole soybean were shown to have a significantly higher yield and the LAI values than the intercropping system. The results of LER confirmed that the 1 maize +2 soybeans in the alternate rows were preferable among the all intercropped yields. Finally, it can be concluded that the combination of intercropping and Vitormone was found suitable for the poor nodulating conditions in the monocropped agricultural system.

\section{References}

Acikgoz N, Akkas M E, Moghaddam A \& Ozcan K (1994). Database dependent Turkish statistical software for PC's: TARIST 1th Congress of Field Crops, Izmir, Turkey. Vol. 1, 264-267 pp [In Turkish]

Addo-Quaye A A, Darkwa A A \& Ocloo K G (2011). Yield and productivity of component crops in a maize-soybean intercropping system as affected by the time of planting and spatial arrangement. Journal of Agricultural and Biological Science 6(9): 50-57

Chen P, Song C, Liu X M, Zhou L, Yang H, Zhang X, Zhou Y, Du Q, Pang T, Fu Z, Wang X, Liu W, Yang F, Du J, Liu J, Yang W, Yong T (2018). Yield advantage and nitrogen fate in an additive maize-soybean relay intercropping system. Science of the Total Environment. 657(2019): 987-999

Cochran W G \& Cox G M (1950). Experimental Design. New York John Wiley \& Sons, Inc. Chapman \& Hall, Limited London, pp. 468

Dolijanvic Z, Kovacevic D, Oljaca S \& Simic M (2009). Types of interactions in intercropping of maize and soybean. Journal of Agricultural Sciences 54(3): 179-187

Gaikwad A L, Deokar C D, Shete M H \& Pawar N B (2008). Studies on the effect of phyllosphere diazotrophs on growth and yield of groundnut. Journal of Plant Disease Sciences 3(2): 182-184

Ghosh P K \& Dayal D (1998). Effect of varying levels of nitrogen in three groundnut based intercropping systems. In Proc. Int. Conf. on Food Security and Crop Sci., CCS Haryana Agricultural University, Hissar pp. 133

Golenberg E M \& West W N (2013). Vitormoneal interactions and gene regulation can link monoecy and environmental plasticity to the evolution of dioecy in plants. American Journal of Botany 100(6): 1022-1037

Hirpa T (2013). Effect of interceding date on growth and yield of three legume crops intercropped with maize (Zea mays L.). Journal of Biological and Chemical Research 30(2): 652-673

Ijoyah M O \& Fanen T F (2012). Effects of different cropping pattern on performance of maize-soybean mixture in Makurdi, Nigeria. Scientific Journal of Crop Science 1(2): 39-47

Ijoyah M O, Ogar A O \& Ojo G O S (2013). Soybean-maize intercropping on yield and system productivity in Makurdi, Central Nigeria. Scientific Journal of Crop Science 2(4): 49-55

Kamara A, Tofa A, Ademulegun T, Solomon R, Shehu H, Kamai N \& Omoigui L (2017). Maize-soybean intercropping for sustainable intensification of cereal-legume cropping systems in Northern Nigeria. Experimental Agriculture 55(1): 1-15

Khan A M, Kawsar A, Zahid H \& Afridi A R (2012). Impact of maize-legume intercropping on weeds and maize crop. Pakistan Journal Weed Science Research 18(1): 127-136 
Kim J, Song Y, Kim D W, Fiaz M \& Kwon C H (2018). Evaluating different interrow distance between corn and soybean for optimum growth, production and nutritive value of intercropped forages. Journal of Animal Science and Technology 60(1): 1

Koushal S \& Singh P (2011). Effect of integrated use of fertilizer, FYM, and biofertilizer on growth and yield performance on soybean (Glycine $\max$ (L.) Merr.). Research Journal of Agricultural Science 43(3): 193-197

Kubota A, Safina S A, Shebl S M, Mohamed A E D H, Ishikawa N S, Katsuyoshi N, Abdel-Gawad K \& Maruyama S (2015). Evaluation of intercropping systems of maize and leguminous crops in the Nile Delta of Egypt. Tropical Agriculture Development 59(1): 14-19

Li L, Sun J H, Zhang F S, Li X L, Yang S C \& Rengel Z (2001). Wheat/maize and wheat/soybean strip intercropping: I. Yield advantage and interspecific interactions on nutrients. Field Crops Research 71(2): 123-137

Liu X, Rahman T, Song C, Su B, Yang F, Yong T \& Yang W (2017). Changes in light environment, morphology, growth, and yield of soybean in maize-soybean intercropping systems. Field Crops Research 200(2017): 38-46

Lv Y, Francis C, Wu P, Chen X \& Zhao X (2014). Maize-soybean intercropping interactions above and below ground. Crop Science 54(3): 914-922

Mahallati M N, Koocheki A, Mondani F, Feizi H \& Amirmoradi S (2014). Determination of optimal strip width in strip intercropping of maize (Zea mays L.) and bean (Phaseolus vulgaris L.) in Northeast Iran. Journal of Cleaner Production 106(3): 390-404

Mandal M K, Banerjee M, Banerjee H, Pathak A \& Das R (2014). Evaluation of cereal-legume intercropping systems through productivity and competition ability. Asian Journal of Science and Technology 5(3): 233-237

Mohiuddin M., Das, A.K. \& Ghosh, D.C. (2000). Growth and productivity of wheat as influenced by integrated use of chemical fertilizer, biofertilizer, and growth regulator. Indian Journal of Plant Physiology 5(4): 334-338

Nasri R, Kashani A, Barary M, Paknejad F \& Vazan S (2014). Nitrogen uptake and utilization efficiency and the productivity of wheat in a double-cropping system under different rates of nitrogen. International Journal of Biosciences 4(4): 184-193

Ngalamu T N, Ashraf M \& Meseka S (2013). Soybean (Glycine max (L.) Merr.) genotype and environment interaction effect on yield and other related traits. American Journal of Experimental Agriculture 3(4): 977-987

Ngwira A R, Aune J B \& Mkwinda S (2012). On-farm evaluation of yield and economic benefit of short term maize legume intercropping systems under conservation agriculture in Malawi. Field Crops Research 132(2012): 149-157

Nyoki D \& Ndakidemi A K (2018) Yield response of intercropped soybean and maize under rhizobia (Bradyrhizobium japonicum) inoculation, and $\mathrm{P}$ and $\mathrm{K}$ fertilization. Communications in Soil Science and Plant Analysis 49(10): 1168-1185

Ofori F \& Stern W R (1987). Cereal-Legume Intercropping systems. Advanced Agronomy 41: 41-90

Osang P O, Richard B I \& Iheadindueme C A (2014). Influence of date of planting and time of introduction of maize on the agronomic performance of soybean-maize intercrop in Nigerian Southern-Guinea Savanna. Journal of Biology, Agriculture and Healthcare 4(3): 2224-3208

Osman G A, Elaziz A I F \& Elhassa A G (2010). Effects of biological and mineral fertilization on yield, chemical composition and physical characteristics of faba bean (Vicia faba L.) cultivar Seleim. Pakistan Journal of Nutrition, 9(7): 703-708

Rahman T, Liu X, Hussain S, Ahmed S, Chen G, Yang F, Chen C L, Du J, Liu W \& Yang W (2017). Water use efficiency and evapotranspiration in maize-soybean relay strip intercrop systems as affected by planting geometries. PLoS ONE 12(6): e0178332

Ramteke S D R D, Kanitkar S, Raut V M \& Sawant S D (2016). The potential of Vitormone (Azotobocfer chroococcum) - Liquid biofertilizer, along with cppu on quality characters and yield of Thompson seedless grapes. Pestology 40(8): 21-28

Salih S H, Hamid, M A S \& Dagash I M Y (2014). The seasonal impact on nodulation, growth, and yield of soybean. Journal of Biological Pharmaceutical and Chemical Research 1(1): 218-222

Sensoy S, Peterson T, Alexander L \& Zhang X (2007) Enhancing Middle East climate change monitoring and indexes. Bulletin of the American Meteorological Society 88(1): 1249-1254

Subowo Y B, Sugiharto A \& Widawati S D S (2010). The test of Kalbar biofertilizer potency for increasing soybean (Glycine max (L.) Merr.) var. Baluran productivity. Caraka Tani: Journal of Sustainable Agriculture 25(1): 112-118

Tahir M M, Abbasi M K, Rahim N, Khaliq A \& Kazmi M H (2009). Effects of Rhizobium inoculation and NP fertilization on growth, yield, and nodulation of soybean (Glycine max (L.) Merr.) in the sub-humid Hilly Region of Rawalakot Azad Jammu and Kashmir, Pakistan. African Journal of Biotechnology, 8(22): 6191-6200

Tsujimoto Y, Pedro J A, Boina G, Murracama M V, Ito O, Tobita S, Oya T, Cuambe C E \& Martinho C (2015). Performance of maize-soybean intercropping under various $\mathrm{N}$ application rates and soil moisture conditions in Northern Mozambique. Plant Production Science 18(3): $365-376$

Uddin M, Hussain S, Khan A M M, Hashmi N, Idrees M, Naeem M \& Dar A T (2014). Use of N and P biofertilizers reduces inorganic phosphorus application and increases nutrient uptake, yield, and seed quality of chickpea. Turkish Journal of Agriculture and Forestry 38(1): 47-54

Undie L U, Uwah F D \& Attoe E E (2012). Effect of intercropping and crop arrangement on yield and productivity of late-season maize/soybean mixtures in the humid environment of south Southern Nigeria. Journal of Agricultural Science 4(4): 37-50

Verdelli D, Acciaresi A H \& Leguizamon S E (2012). Corn and soybeans in a strip intercropping system: crop growth rates, radiation interception, and grain yield components. International Journal of Agronomy 2012: 1-17

Walker S \& Ogindo H O (2003). The water budget of rainfed maize and bean intercrop. Physics and Chemistry of the Earth 28:919-926

Yavas I \& Unay A (2016a). Evaluation of physiological growth parameters of maize in maize-legume intercropping system. Journal of Animal \& Plant Sciences 26(6): 1680-1687

Yavas I \& Unay A (2016b). Effect of maize/legume intercropping on crop productivity and soil compaction. Anadolu Journal of Agricultural Sciences 31(2): 268-274

Yong T, Liu X, Yang F, Song C, Wang X, Liu W \& Yang W (2015). Characteristics of nitrogen uptake, use and transfer in a wheat-maizesoybean relay intercropping system. Plant Production Science 18(1): 388-397 